\title{
Development of Agrotourism and Its Impact on Regional Tax Revenue
}

\author{
${ }^{1}$ JAKA SULAKSANA, ${ }^{2}$ DADANG SUDIRNO, ${ }^{3}$ L. SUPARTO L.M

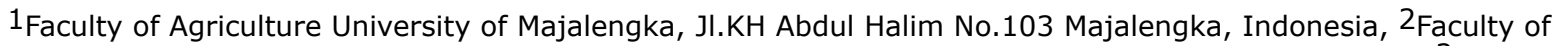 \\ Economica and Business University of Majalengka, Jl. KH Abdul Halim No.103 Majalengka, Indonesia 2Faculty \\ of Economica and Business University of Majalengka, Jl. KH Abdul Halim No.103 Majalengka, Indonesia \\ email: ${ }^{1}$ jsulaksana@unma.ac.id ; ${ }^{2}$ dsudirno@gmail.com; ${ }^{3}$ lalusuparto@gmail.com
}

\begin{abstract}
Majalengka government has taken agrotourism approach in economic development as autonomy implementation. The development of agrotourism potentials is hoped to make contribution to regional income, including tax subsector. This study aims (1) to discover the progress of regional tax contributions in the last few years; and (2) to find out the impact of international airport existence to the rise of regional income. The method used is quantitative and qualitative descriptive method. The research location is in Majalengka Regency. Data is collected from primary and secondary data. Primary data is the result of a survey conducted on 1891 taxpayers, while secondary data is the achievement of tax revenue each year from Regional Income Office. The collecting data is conducted in June-September 2020. The analysis technique used is overlay analysis which is started with potential and growth analysis. The results show that the largest contributions to regional original income are restaurant and advertisement tax. It is due to a large increase in the number of taxpayers of the two sub-taxes. The results also show that five types of sub-taxes have an average contribution rate of $36.20 \%$ to regional original income, and included in the sufficient category, meaning that the Regional Government of Majalengka Regency need to optimize its tax revenue. The existence of Kertajati International Airport has made a change in social economic life of Majalengka society. There is an expanding of business scale not only around the airport but also in other area including highland as the basis of Agrotourism.
\end{abstract}

Keywords: agrotourism, regional taxes, contribution analysis

\section{Introduction}

The issuance of Law Number 22 Year 1999 concerning the development of broad regional autonomy from the central government to provincial and district/ city governments and Law no. 33 of 2004 concerning Central and Regional Financial Balance, causing the allocation of tasks, functions of authority and responsibility for environmental management which have been concentrated in the central government will now delegate it to regional governments. Hence the role and involvement of the community will be increasingly dominant and provide great opportunities for regions to manage their own natural resources in order to provide optimal results. Today's economic development requires the government and society to develop and utilize the potential of a region in order to support the economy to a better direction. The implementation of regional autonomy which focuses on districts/cities begins with the transfer of a number of authorities or affairs from the central government to the relevant regional governments. Admittedly, the implementation of regional autonomy by the government is more focused on increasing regional income that reflects regional independence in managing its finances. Regional development policy strategies are the key to increasing regional independence (Carpio et al., 2008; Giaccio, Mastronardi, et al., 2018).

One of the regional development policies in Jawa Barat Province is the construction of Jawa Barat International Airport Kertajati which was started in 2012 and has been operated since 2017. This program is one of the policies to develop an

Received: August 30, 2020, Revision: June 10, 2021, Accepted: June 25, 2021

Print ISSN: 0215-8175; Online ISSN: 2303-2499. DOI: https://doi.org/10.29313/mimbar.v37i1.6602

Accredited Sinta 2 based on the decree No.10/E/KPT/2019 until 2024. Indexed by DOAJ, Sinta, Garuda, Crossreff, Dimensions 
economic development center in the eastern region of Jawa Barat. Located in Majalengka Regency, one of the economic centers in the Ciayumajakuning area (Cirebon, Indramayu, Majalengka, and Kuningan), it is intended that the development of the Kertajati airport can encourage even more rapid economic growth in the region.

If it looked more narrowly, Majalengka Regency is an area with agricultural sector as its main potential; however, it is predicted that the sector that will develop rapidly is the agrotourism sector. Majalengka government has released agrotourism development approach to accelerate economic development. This approach has been taken based on the existence of Majalengka area that mostly located in the highlands which has great potential for agrotourism development. With the Kertajati airport, areas that have tourism potential have the opportunity to develop even better, both socially and economically (Jęczmyk et al., 2015; Okech et al., 2012). Through the operation of the Kertajati Airport, it is hoped that regional economic growth can be achieved (Giaccio, Giannelli, et al., 2018; Lupi et al., 2017; Muhammad et al., 2012).

The question that arises is how much the agrotourism development approach has an effect on regional income. One sector that is expected to grow is the local tax sector. Through the existence of Kertajati Airport and the growth of agrotourism sector, it is hoped that regional tax revenue as one source of regional income can also increase. This study is to determine how much the progress of regional tax contributions in recent years and to find out the impact of the existence of Kertajati international airport to the rise of regional income.

\section{Research Methodology}

The method used is mix method (quantitative and qualitative approach) (Sugiono, 2008; Sugiyono, 2007, 2011). The research location is the area of Majalengka Regency with the unit of analysis is income realization in Majalengka Regency area. The data was collected from secondary data and primary data. Secondary data is the achievement or realization of tax revenue for each year (collected from Regional Income office) and primary data is the result of a structured questionnaire to taxpayers and interviews with some officers.

The population of this study is all taxpayers in each sub-tax area. The sample is determined by means of a census or the entire population is used as a sample (Arikunto, S, 2012; Arikunto, 2007). Table 1 below is data on taxpayers per sub-tax area according to data obtained from the Regional Planning Agency of Majalengka Regency.

Based on table 1 above, it can be seen that the total population and sample in this study were 1,891 taxpayers. Survey was conducted by some enumerators in June until September 2020.

Overlay analysis is used to get the mapping of income tax potential from each sub sectors. Overlay analysis includes contribution and growth analysis and potential analysis (Ratnasari, 1970; Siren, 2016). Contribution analysis is carried out to determine the contribution of each subtax to PAD (regional original income); the analysis technique used is the contribution, growth analysis, potential analysis and Klasen Typology with the following formula:

Table 1

Population and Sample

\begin{tabular}{clc}
\hline No & \multicolumn{1}{c}{ Type of Regional Tax } & Number of Taxpayers \\
\hline 1 & Hotel tax & 51 \\
2 & Restaurant tax & 438 \\
3 & Parking tax & 43 \\
4 & Advertisement tax & 1.321 \\
5 & Entertainment tax & 38 \\
& $\quad$ Total & $\mathbf{1 . 8 9 1}$ \\
\hline
\end{tabular}

Source: Body of Regional Income of Majalengka, 2020 


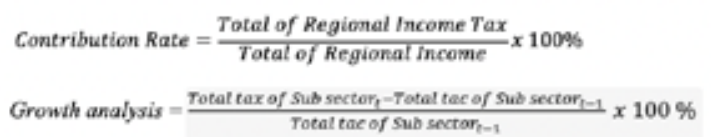

Overlay analysis is conducted using Klasen typology with the matrix below:

Table 2. Overlay Formula (Klasen Typology)

\begin{tabular}{ccc}
\hline $\begin{array}{c}\text { Sector of } \\
\text { Contribu- } \\
\text { tion }\end{array}$ & \multicolumn{2}{c}{ Sector of Growth } \\
\cline { 2 - 3 } si $\geq \mathrm{s}$ & $\begin{array}{c}\text { Sector has } \\
\text { developed and } \\
\text { grow rapidly }\end{array}$ & $\begin{array}{c}\text { Sector has } \\
\text { developed but } \\
\text { depressed }\end{array}$ \\
& $\begin{array}{c}\text { Sector has a } \\
\text { potential to } \\
\text { si }<\mathrm{s}\end{array}$ & $\begin{array}{c}\text { Relatively } \\
\text { lagging sector }\end{array}$ \\
& growidly & \\
\end{tabular}

Potential analysis uses a formula as follows:

$$
\begin{gathered}
\mathrm{HI}=\mathrm{NHtl} \times \text { AVE } \times \text { ARS } \times \mathrm{ND} \\
\mathrm{VHTP}=\mathrm{PH} \times \mathrm{Tp}
\end{gathered}
$$

$\mathrm{HI}=$ Hotel Income (Rupiah)

VHTP $=$ Value of Hotel Tax Potential (Rupiah)

$\mathrm{NHtl}=$ Number of Hotel (Unit)

AVE = Average of Visitor Expense (Rupiah/ Unit)

ARS = Average of Room Stayed (Unit/Hari)

$\mathrm{ND}=$ Number of Days (days)

$\mathrm{TT}=$ Tax Tariff $(\%)$

The qualitative method is used to describe the impact of Kertajati International airport to the rise of regional income. Correlation explanation is conducted to see the relation of the existence of factors and the growth of regional economic. Some data is used in this effort.

\section{Results and Discussion}

The topography of Majalengka Regency in general can be divided into 3 (three) parts: sloping or lowland (0 - 15 percent), rolling hills (15 - 40 percent), and steep hills ( $>40$ percent). As much as 13.21 percent of the total area of Majalengka Regency is in a land slope of above 40 percent, 18.53 percent is in the $15-40$ percent slope class, and 68.26 percent is in the $0-15$ percent slope class. The condition of the landscape is sloping to the Northwest area, causing most of the rivers and springs to flow to the North so that there are many rice fields in the northern part of Majalengka Regency. There are hills with steep slopes on the slopes of Mount Ciremai and areas on the slopes of Mount Cakrabuana. This topographical condition greatly influences the use of space and potential for regional development, as well as causing an impact that results in areas prone to land movement, namely areas with steep slopes.

The distribution of the three topographies in Majalengka Regency as mentioned above is as follows: (1) Lowland, has a land slope of $0-15 \%$, covering all sub-districts in Majalengka Regency. The sub-districts that have a slope of $0-15 \%$ of their entire territory consist of Cigasong, JatitTujuh, Jatiwangi, Kadipaten, Kertajati, Ligung, and Palasah District; (2) Hilly waves, the slope of the land ranges from $15 \%$ to $40 \%$, covering Argapura, Banjaran, Bantarujeg, Malausma, Cikijing, Cingambul, Dawuan, Kasokandel, Lemahsugih, Maja, Majalengka, Rajagaluh, Sindangwangi, Sukahaji, Sindang and Talaga sub-districts; (3) The hills are steep, the land slope is $>40 \%$, covering the area around Mount Ciremai, Argapura, Banjaran, Bantarujeg, Malausma, Cikijing, Cingambul, Lemahsugih, Leuwimunding, Maja, Majalengka, Panyingkiran, Rajagaluh, Sindangwangi, Sukahaji, Sindang, Sumberjaya and Talaga sub-district.

Meanwhile, based on the altitude, the area of Majalengka Regency is classified into 3 (three) main classifications, namely lowland ( $0-100 \mathrm{~m}$ asl), medium land ( $>100$ - $500 \mathrm{~m}$ asl), and highland (> $500 \mathrm{~m}$ asl). The lowlands of 42.21 percent of the total area are located in the Northern Territory of Majalengka Regency; the moderate plains are 20.82 percent of the total area, generally located in the Central Region; and the highlands are 36.97 percent of the total area, dominating the Southern Region of Majalengka Regency including areas at an altitude of 2,000 m above sea level, which is located around the area of the foot of Mount Ciremai.

Quoted from the Master Plan for Regional Tourism Development of Majalengka Regency in 2010, DISPARBUD has a vision for the period of 2010-2025, namely to realize Majalengka Regency as an ecotourism destination of agro-natural and cultural arts 


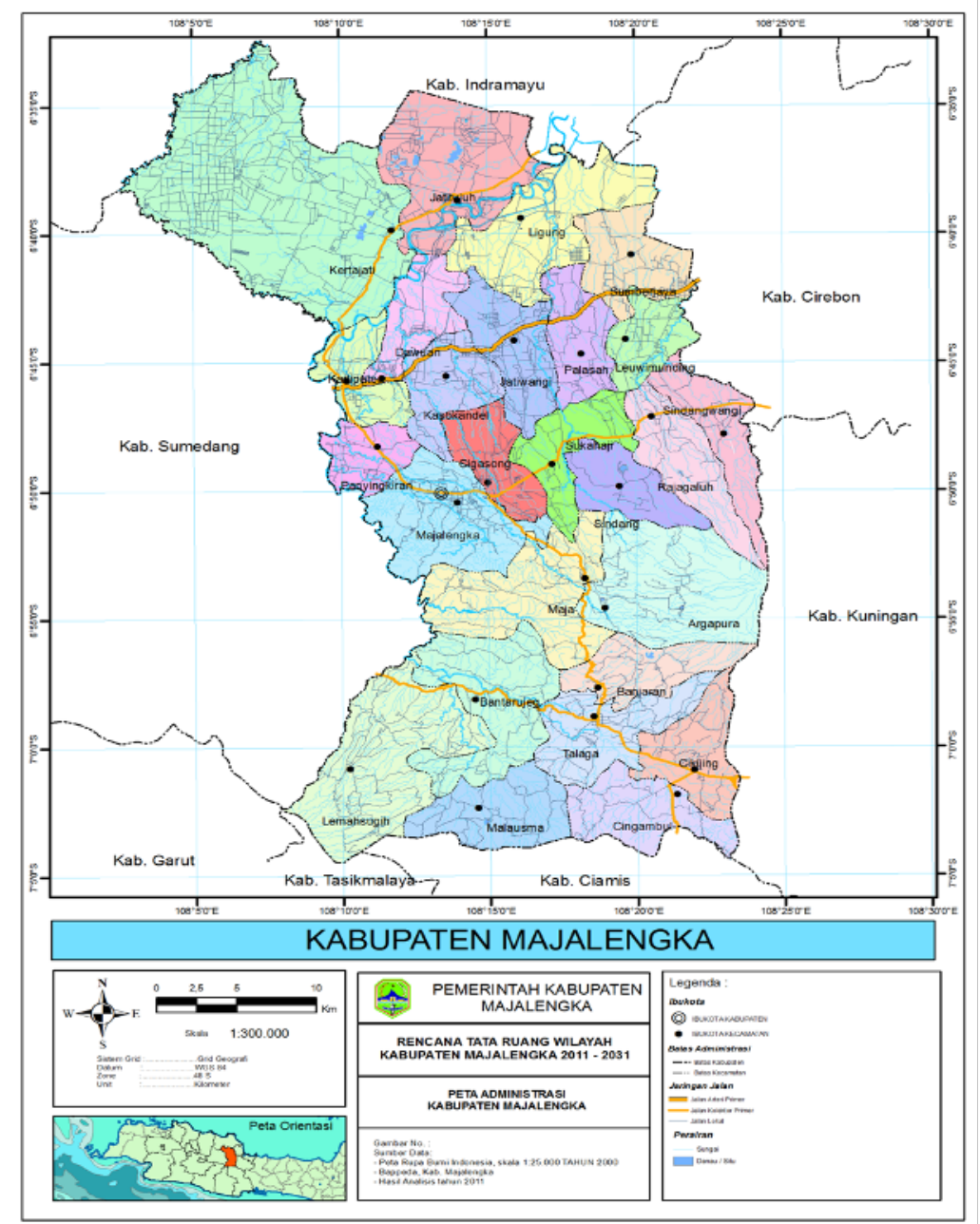

Figure 1. Map of Majalengka Region

that is competitive and sustainable and based on a community of faith and piety by 2025. To achieve this vision, the Disparbud Majalengka Regency has set a mission as follows:

(a) Developing agro-natural tourism destinations and cultural arts that are internationally competitive through the protection, development and management of mountainous natural tourism resources, agriculture, as well as traditional and contemporary cultural arts that support tourism in Majalengka Regency in a sustainable manner; (b) Build and develop a creative tourism industry that favors local communities, is competitive and cultured, as well as develop industrial networks nationally and internationally to support the economy of Majalengka Regency; (c) Develop responsible and integrated tourism marketing and promotion with other economic sectors in Majalengka Regency, and with other tourism destinations in
Jawa Barat and nationally; (d) Build and improve the tourism institutional system and empower local human resources who are faithful and devoted to strengthening the role of the community in tourism development in Majalengka Regency.

Based on the Regional Regulation of Jawa Barat Province No. 15 of 2015 concerning the Jawa Barat Province Tourism Development Master Plan, it has a vision of making Jawa Barat a world-class tourism destination that is integrated, sustainable, and upholds cultural values. In realizing this vision, four missions are pursued, namely building world-class tourism destinations, a strong and integrated industrial structure, effective marketing, and tourism institutions capable of enhancing development integration. This vision and mission is embodied in tourism destination development policies. The policy also regulates Majalengka Regency policies as follows: 
Table 3.

Regulations in Relation with Majalengka in Jawa Barat Plan 2015 - 2025

\begin{tabular}{|c|c|c|}
\hline No & $\begin{array}{l}\text { Article, } \\
\text { Verse }\end{array}$ & Regulation \\
\hline 1 & $\begin{array}{l}\text { Article 27, } \\
\text { paragraph } \\
1(f)\end{array}$ & $\begin{array}{l}\text { Majalengka Regency is included in KPPP (Kawasan Pengembangan Pari- } \\
\text { wisata Provinsi/Area of Tourism Development in Jawa Barat) covering } \\
\text { area of ecotourism of mountainous Majalengka- Kuningan and its sur- } \\
\text { rounding. }\end{array}$ \\
\hline 2 & Article $33(a)$ & $\begin{array}{l}\text { Plan of KPPP Development area of ecotourism Majalengka- Kuningan } \\
\text { and its surrounding and has a theme of ecotourism }\end{array}$ \\
\hline 3 & Article 33 (b) & Majalengka Regency is included in primary attraction of tourism \\
\hline
\end{tabular}

Based on data on tourist visits to Majalengka Regency obtained from the Department of Tourism and Culture of Jawa Barat Province, it is known that the growth of visitors in Majalengka Regency has increased every year. The following is a projection of visitors to the Bukit Panyaweuyan tourist area in the next 10 years which is calculated using the geometric method.

It has been mentioned above that the accommodation and food and beverage sectors continue to increase. This phenomenon can be seen from the increase in the number of restaurants, hotels and inns in the framework of providing services to the tourism sector in Majalengka Regency. This indicates a stretch in the economic sector which is driven by the tourism sector (Kristiana \& Theodora, 2016) and (Marin, 2015), as shown in table 5 below. Majalengka Regency has experienced great changes in number of restaurant. It is followed by Kadipaten Sub District, Jatiwangi Sub District, and Maja Sub District. Kadipaten and Jatiwangi are the areas which are relatively close to the new airport. In the other side, Maja Sub District is located in mountainous area and has great potential for agrotourism. Recently, many restaurants have been operated at the surrounding of tourism place, such as panyaweuyan and lakes. Some of them are local restaurants owned by local persons and relatively small, but others are owned by outsiders and relatively big. However, the most increased restaurants are in three

Table 4.

Projection of visitors of Majalengka Upland (Panyaweuyan)

\begin{tabular}{cc}
\hline Year & Number of Visitors \\
\hline 2016 & 35,182 \\
2017 & 39,681 \\
2018 & 45,871 \\
2019 & 55,678 \\
2020 & 59,896 \\
2021 & 68,417 \\
2022 & 78,151 \\
2023 & 89,270 \\
2024 & 101,971 \\
2025 & 116,478 \\
2026 & 133,050 \\
2027 & 151,979 \\
2028 & 173,601 \\
2029 & 198,300 \\
2030 & 226,512 \\
\hline Source: Office of tourism and culture, Jawa Barat Province
\end{tabular}


areas, namely Majalengka, as the centre of region, Jatiwangi and Kadipaten Subdistrict. The rise in Jatiwangi and Kadipaten is caused by the existence of Kertajati International Airport.

From table 6 , it can be seen that since 2015, there has been an increase in the number of hotels and inns in Majalengka Regency, especially in number of rooms.
From 2015-2017, there was an increase almost 100 percent for the number of rooms. It could be caused by the operation of Jawa Barat International Airport (BIJB) Kertajati which has encouraged the growth of other service sectors. It can be predicted that in the future, there is a possibility that this number will continue to increase along with the increase in the tourism and

Table 5.

Number of Restaurant in Majalengka Regency in 2017-2019

\begin{tabular}{|c|c|c|c|}
\hline SUB DISTRICT & 2017 & 2018 & 2019 \\
\hline (1) & (2) & (3) & (4) \\
\hline Lemahsugih & - & - & - \\
\hline Bantarujeg & - & 1 & - \\
\hline Malausma & - & - & - \\
\hline Cikijing & 5 & 6 & 7 \\
\hline Cingambul & - & - & - \\
\hline Talaga & 4 & 4 & 4 \\
\hline Banjaran & - & - & - \\
\hline Argapura & - & - & - \\
\hline Maja & 8 & 10 & 8 \\
\hline Majalengka & 76 & 66 & 55 \\
\hline Cigasong & 8 & 7 & 6 \\
\hline Sukahaji & 5 & 2 & 2 \\
\hline Sindang & - & - & - \\
\hline Rajagaluh & 2 & 4 & 1 \\
\hline Sindangwangi & 3 & 6 & 9 \\
\hline Leuwimunding & 1 & 1 & 1 \\
\hline Palasah & - & - & - \\
\hline Jatiwangi & 10 & 17 & 8 \\
\hline Dawuan & 2 & 3 & 1 \\
\hline Kasokandel & 1 & - & - \\
\hline Panyingkiran & - & 1 & 1 \\
\hline Kadipaten & 20 & 17 & 20 \\
\hline Kertajati & 2 & 1 & 4 \\
\hline Jatitujuh & 2 & 4 & 5 \\
\hline Ligung & - & - & - \\
\hline Sumberjaya & 2 & 1 & 3 \\
\hline Majalengka Regency & 151 & 151 & 135 \\
\hline
\end{tabular}


transportation sectors. There are some places that have great potential to attract the tourist, such as Panyaweuyan at Argapura Subdistrict, Cipanten Lake at Sindangwangi subdistrict, and River tubbing at Payung Village. Panyaweuyan is the most potential in Majalengka Tourism. It is a kind of place or hill which is built with a terraced system of horticulture. It has been proposed as NIAHS (National Important Agriculture Heritage System). The numbers of visitors who visit Panyaweuyan are increasing year by year. It shows that this place can attract tourist (Tirtawinata et al., 1996).

The existence of Kertajati International Airport has become a separate force for other tourism sectors around the airport. There has been an increase in the number of restaurants around the airport because the transportation sector and the tourism sector and the related services therein have a strong attachment.

If it is related to regional revenue, then the regional revenue from the tax sector should increase along with the addition or increase in the existence of tourism and transportation sector. The rising number of restaurant, coffee shop, especially at tourism area can be predicted to occur in the future. At present, there are more than a hundred place of tourism in Majalengka that have already managed to be a place with conformity, friendliness, and full of beauty. It is kind of community development based tourism (Mazilu, 2010; Polena et al., 2013; Subhilhar, 2018). On the other side, it is important to maintain these resorts to be a sustainable tourism that generate sustainable regional revenue (Jolink \& Niesten, 2015; Muzha, 2013; Yeretzian, 2017)

There are several analyzes carried out

Table 6.

The Number of Hotel and Inn in Majalengka, 1997-2017

\begin{tabular}{ccc}
\hline Year & Number of Inn & Number of rooms \\
\hline 1997 & 9 & 200 \\
1998 & 9 & 200 \\
1999 & 9 & 163 \\
2000 & 9 & 170 \\
2001 & 8 & 161 \\
2002 & 8 & 176 \\
2003 & 8 & 176 \\
2004 & 9 & 192 \\
2005 & 9 & 192 \\
2006 & 9 & 192 \\
2007 & 9 & 193 \\
2008 & 9 & 192 \\
2009 & 9 & 191 \\
2010 & 9 & 190 \\
2011 & 9 & 190 \\
2012 & 9 & 193 \\
2013 & 9 & 197 \\
2014 & 9 & 193 \\
2015 & 12 & 233 \\
2016 & 15 & 401 \\
2017 & 15 & 401 \\
\hline & Source & Statistcal bureau of Majalengka, 2019 \\
& & \\
\hline
\end{tabular}


Table 7.

The Contribution of Regional Tax to Regional Income (IDR)

\begin{tabular}{ccccccc}
\hline Year & Regional Income & Hotel tax & $\begin{array}{c}\text { Restaurant } \\
\text { tax }\end{array}$ & $\begin{array}{c}\text { Entertain- } \\
\text { ment tax }\end{array}$ & Parking tax & $\begin{array}{c}\text { Advertisement } \\
\text { tax }\end{array}$ \\
\hline 2014 & $142,809,856,488$ & $140,000,000$ & $1,400,000,000$ & $70,000,000$ & $75,000,000$ & $1,200,000,000$ \\
2015 & $283,735,793,231$ & $211,527,500$ & $2,216,218,267$ & $236,411,730$ & $122,409,900$ & $2,062,608,684$ \\
2016 & $331,527,582,021$ & $242,800,300$ & $2,931,947,154$ & $230,160,370$ & $185,093,800$ & $2,557,058,043$ \\
2017 & $513,783,824,022$ & $255,747,100$ & $2,878,288,995$ & $300,191,150$ & $413,539,800$ & $2,581,472,532$ \\
2018 & $449,974,129,889$ & $486,279,138$ & $4,181,441,892$ & $312,269,179$ & $622,953,970$ & $3,108,559,986$ \\
2019 & $473,449,999,993$ & $665,763,000$ & $5,090,500,000$ & $464,320,000$ & $767,740,000$ & $2,900,000,000$ \\
\hline
\end{tabular}

Source: Ministry of Finance, 2020

in assessing the potential for this regional tax, including contribution analysis. By using primary data and secondary data obtained from the results of data collection on 1,891 taxpayers, a contribution analysis can be carried out as follows:

Contribution analysis is conducted to determine how much the contribution of sub taxes to Regional Original Income (PAD)

From the table above, it can be seen that the income from restaurant tax has become the highest compared to others with the value of more than 5 billion rupiahs in 2019. This value shows a significant increase than previous years. The second is advertisement tax, and followed by hotel tax, parking tax, and entertainment tax. The entertainment tax becomes the lowest predicted regional income because the social culture of Majalengka is the religious region with devout Muslims, therefore the entertainment service or location has been stagnant in Majalengka.
The largest contribution to PAD (Regional Original Revenue) comes from restaurant tax and advertisement tax. This can be understood because there has been an increase in the number of large taxpayers from the two sub-taxes along with the increase or development of the economic area in Majalengka Regency as a result of the operational of BIJB Kertajati (Octovido, 2014)in line with the decentralization, the financing aspect also decentralized. Methods This study used a descriptive research. Where his research at Batu City Regional Revenue Office. The data used in this study is a secondary data. This study uses data Batu City Regional Revenue from year 2009 to 2013. Analysis of the results showed that in 2010 had the lowest effectiveness (69.30\%. The illustration of the contribution of local taxes for each object to Regional Original Income (PAD) can be seen from the following diagram:

During 2014 - 2019, the contribution of hotel taxes to PAD was relatively small.

Table 8.

The Contribution of Regional Tax to Regional Income (\%)

\begin{tabular}{cccccc}
\hline Year & Hotel & Restaurant & Entertainment & Parking & Advertisement \\
\hline 2014 & 0.10 & 0.98 & 0.05 & 0.05 & 0.84 \\
2015 & 0.07 & 0.78 & 0.08 & 0.04 & 0.73 \\
2016 & 0.07 & 0.88 & 0.07 & 0.06 & 0.77 \\
2017 & 0.05 & 0.56 & 0.06 & 0.08 & 0.50 \\
2018 & 0.11 & 0.93 & 0.07 & 0.14 & 0.69 \\
2019 & 0.14 & 1.08 & 0.10 & 0.16 & 0.61 \\
Average & $\mathbf{0 . 0 9}$ & $\mathbf{0 . 8 7}$ & $\mathbf{0 . 0 7}$ & $\mathbf{0 . 0 9}$ & $\mathbf{0 . 6 9}$ \\
Lowest & $\mathbf{0 . 0 5}$ & $\mathbf{0 . 5 6}$ & $\mathbf{0 . 0 5}$ & $\mathbf{0 . 0 4}$ & $\mathbf{0 . 5 0}$ \\
Highest & $\mathbf{0 . 1 4}$ & $\mathbf{1 . 0 8}$ & $\mathbf{0 . 1 0}$ & $\mathbf{0 . 1 6}$ & $\mathbf{0 . 8 4}$ \\
\hline
\end{tabular}

Source: Primary data, 2020 
Contribution of Hotel Tax to Regional Income

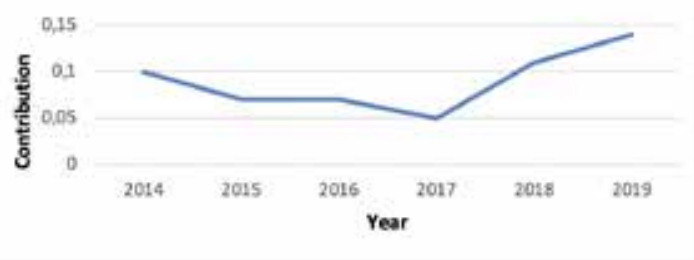

Figure 2. Contribution of Hotel Tax to Regional Income

This is because the quantity or number of hotels in Majalengka Regency is still small, only an average of 13 units.

\section{Contribution of Restaurant Tax to Regional income}

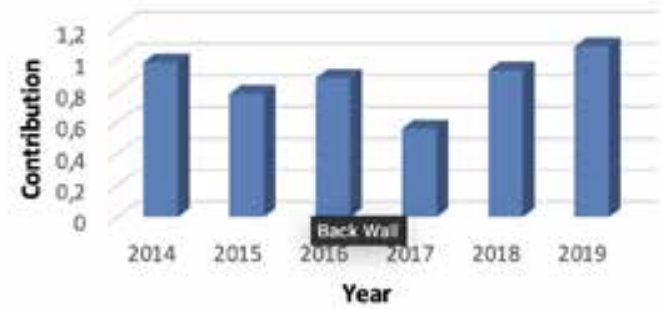

Figure 3. Contribution of Restaurant Tax to Regional Income

Restaurant tax is included in taxes that have a significant contribution to PAD. With the number of more than 100 restaurant units, maybe even still growing, the revenue and contribution of restaurant in the future maybe even greater.

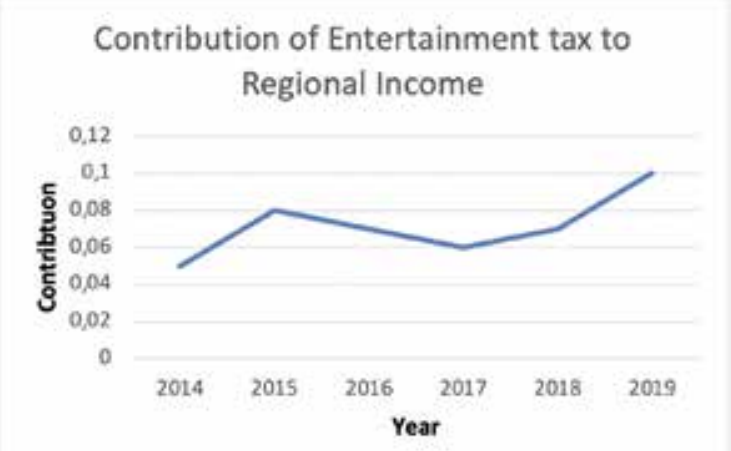

Figure 4. Contribution of Entertainment Tax to Regional Income

During the period 2014 - 2019, entertainment tax was still unable to make a significant contribution to PAD. This is due to the fluctuation in quantity, and socio-cultural factors still have a big influence (Joshi \& Bhujbal, 2012). People of Majalengka are included in a regency that promotes religion, so that the growth in the number of entertainment services is stagnant, even decreasing.

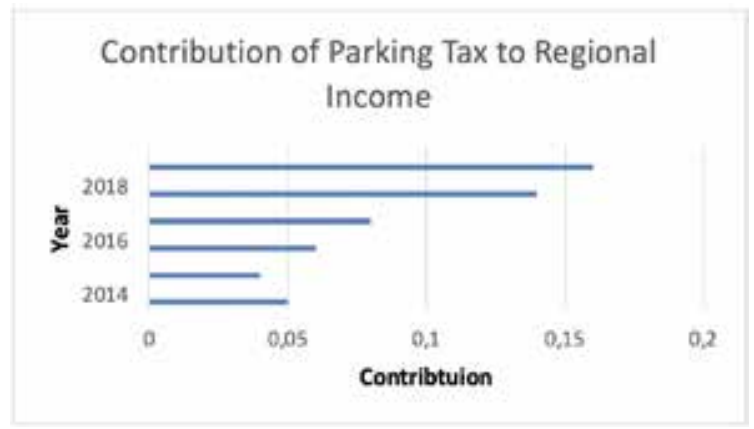

Figure 5. Contribution of Parking Tax to Regional Income

Parking tax is included in taxes that have a positive contribution from year to year. This tax has linearity with hotel and restaurant taxes: the higher the hotel and restaurant taxes, the higher the parking tax. The economic sector in Majalengka Regency develops rapidly, which is driven by the existence of West Java International Airport (BIJB) in Kertajati and the development of tourist attractions in Majalengka Regency.

\section{Contribution of Advertisement Tax to Regional Income}

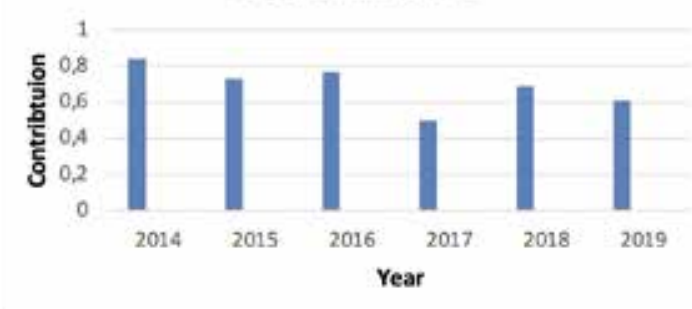

Figure 6. Contribution of Advertisement Tax to Regional Income

Judging from the bar chart above, there is a slight sloping decrease in the contribution of the advertisement tax to PAD. However, in general, the advertisement tax has a large contribution to PAD. The advertisement tax is the second largest contribution tax after restaurant tax.

Actually, from figure 6 we can see that restaurant tax is not the most rapid growth tax, but since it has the large amount of number, it seems like this sub-tax has the highest contribution to the regional income. The entertainment tax, actually, is the most rapid since 2017, but there is a constraint from social behavior or perception. It caused this sub-sector looks like stagnant in the last two years. 
Table 9.

The growth of Income Tax in Majalengka Regency

\begin{tabular}{cccccc}
\hline Year & $\begin{array}{c}\text { (1) Hotel } \\
\text { Tax }\end{array}$ & $\begin{array}{c}\text { (2) Restaurant } \\
\text { Tax }\end{array}$ & $\begin{array}{c}\text { (3) } \\
\text { Entertainment } \\
\text { Tax }\end{array}$ & $\begin{array}{c}\text { (4) Parking } \\
\text { Tax }\end{array}$ & $\begin{array}{c}\text { (5) } \\
\text { Advertisement } \\
\text { Tax }\end{array}$ \\
\hline 2015 & 51.09 & 58.30 & 237.73 & 63.21 & 71.88 \\
2016 & 14.78 & 32.30 & -2.64 & 51.21 & 23.97 \\
2017 & 5.33 & -1.83 & 30.43 & 123.42 & 0.95 \\
2018 & 90.14 & 45.28 & 4.02 & 50.64 & 20.42 \\
2019 & 36.91 & 21.74 & 48.69 & 23.24 & -6.71 \\
Average & $\mathbf{3 9 . 6 5}$ & $\mathbf{3 1 . 1 6}$ & $\mathbf{6 3 . 6 5}$ & $\mathbf{6 2 . 3 4}$ & $\mathbf{2 2 . 1 0}$ \\
Bottom & $\mathbf{5 . 3 3}$ & $\mathbf{- 1 . 8 3}$ & $\mathbf{- 2 . 6 4}$ & $\mathbf{2 3 . 2 4}$ & $\mathbf{- 6 . 7 1}$ \\
Top & $\mathbf{9 0 . 1 4}$ & $\mathbf{5 8 . 3 0}$ & $\mathbf{2 3 7 . 7 3}$ & $\mathbf{1 2 3 . 4 2}$ & $\mathbf{7 1 . 8 8}$ \\
\hline
\end{tabular}

Source: Regional Income Office, counted

From the table of potential tax recapitulation below, it can be seen that the biggest potential tax is advertisement tax, followed by restaurants and then hotels. This data is obtained from primary data of a survey of taxpayers in each sector. This result is quite different from the data that existed before verification, which means that there is a large gap and local tax collection is still not optimal.

Several factors are suspected to have contributed to the suboptimal pattern or system of local tax collection. Limited human resources (HR) of regional apparatus in the inventory of taxpayers, especially in verification and validation, resulted in a bias in the amount of taxpayer receipts. Another factor is the lack of awareness of taxpayers to pay taxes. This is made worse by the absence of regulations covering the expansion or extensification of taxpayers. A better network or cooperation is needed from regional apparatus, in this case, Bapenda with other parties to produce more accurate targets and receipts. Cooperation with universities can be one solution. Digitizing the taxpayer system can increase the accuracy of the potential and revenue of local taxpayers.

Table 10.

Tax Potential in 2020

\begin{tabular}{clc}
\hline No & Type of Tax & Potential (IDR) \\
\hline 1 & Hotel & $11,369,248,435$ \\
2 & Restaurant & $19,364,437,402$ \\
3 & Entertainment & $7,721,681,964$ \\
4 & Parking & $886,871,786$ \\
5 & Advertisement & $64,441,242,722$ \\
\hline
\end{tabular}

Source: Primary data, counted

Table 11.

Comparison between Tax Potential of 2020 and Realization of Tax Income of 2019

\begin{tabular}{lcrrrrr}
\hline No & Type of Tax & $\begin{array}{c}\text { Potential of } \mathbf{2 0 2 0} \\
\text { (IDR }\end{array}$ & $\begin{array}{c}\text { Realization of In- } \\
\text { come 2019 (IDR) }\end{array}$ & \multicolumn{1}{c}{ Gap (IDR) } & \% \\
\hline 1 & Hotel & 11.369 .248 .435 & 665.763 .000 & 10.703 .485 .435 & $-94,14$ \\
2 & Restaurant & 19.364 .437 .402 & 5.090 .500 .000 & 14.273 .937 .402 & $-73,71$ \\
3 & Entertainment & 7.721 .681 .964 & 464.320 .000 & 7.257 .361 .964 & $-93,99$ \\
4 & Parking & 886.871 .786 & 767.740 .000 & 119.131 .786 & $-13,43$ \\
5 & Advertisement & 64.441 .242 .722 & 2.900 .000 .000 & 61.541 .242 .722 & $-95,50$ \\
\hline
\end{tabular}

Source: Primary data, counted 


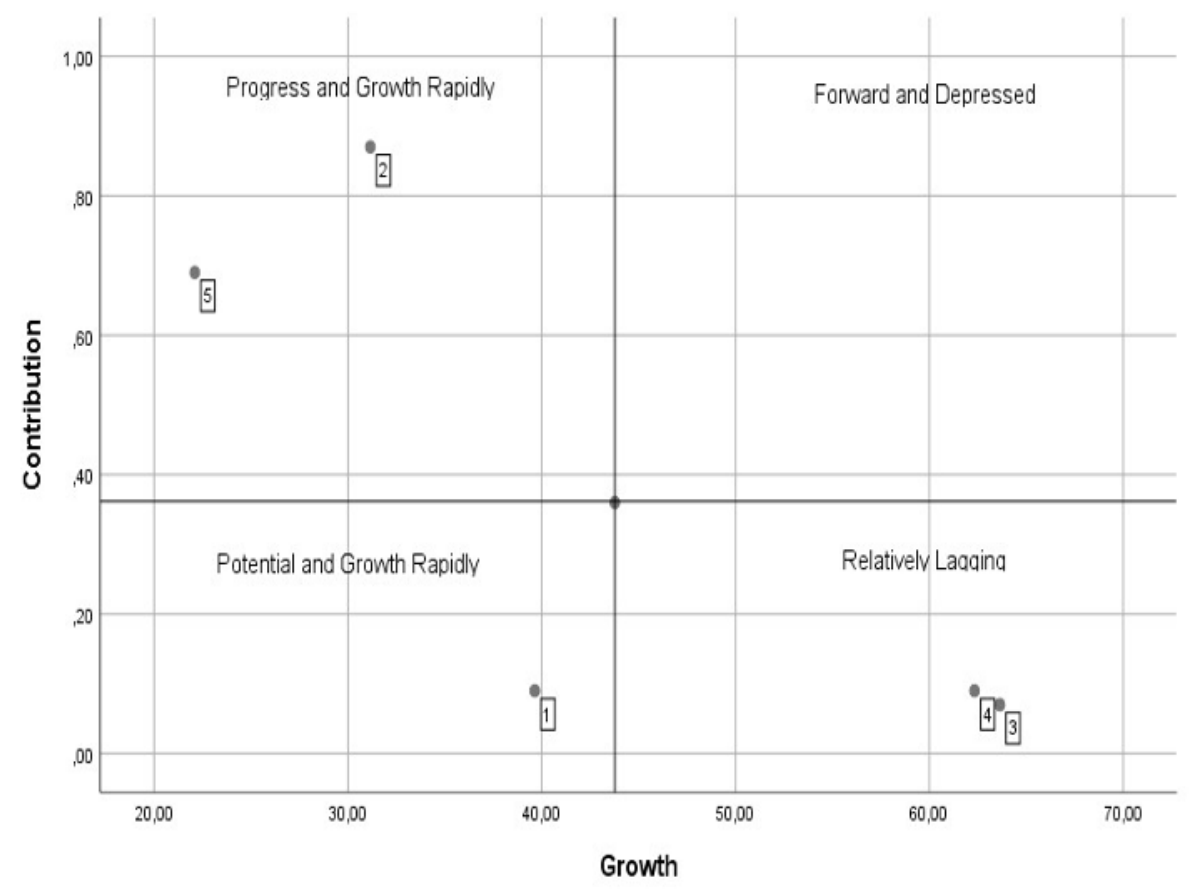

Figure 7. Overlay Map

Quadrant I: Progress and rapid growth

Judging from the contribution and growth, the restaurant and advertisement tax sub-sector is included in this quadrant. The level of economic agglomeration as a result of the Kertajati Airport has brought these two tax sub-sectors experiencing advanced conditions and growing rapidly compared to other sub-taxes. The development of agrotourism, including culinary tourism, has brought a rapid increase in the restaurant sub-tax (Muhammad et al., 2012; Tiraieyari \& Hamzah, 2011). This explanation in line with the result of contribution analysis which shows that restaurant tax has the highest contribution to regional income as a result of economic agglomeration. The fact is number of coffee shop rises rapidly.

\section{Quadrant II: Forward but depressed}

There is no tax sub-sector included in this quadrant because each sub-tax has experienced sharp fluctuations. Sometimes it drops significantly (lags behind) or grows rapidly.

Quadrant III: Potential and can grow rapidly

This quadrant is occupied by hotel tax which has a fairly rapid growth, although the contribution to Regional original income is under restaurant and advertisement tax. The small contribution of hotel tax is due to the relatively small number of hotels and is predicted to continue to grow as the economy around Kertajati airport grows and agrotourism, especially in mountainous area, is running well. The policy of agrotourism is convinced to make the development of regional economic straight forward with the rapid growth of restaurant, coffee shop, culinary shop, and hotels (Arief \& Gill, 2011). The increasing of hotel service is indicated by the rise of room number year by year. In two or three years recently, the number of hotel rooms increase almost one hundred percent. It shows that number of visitors are increasing rapidly.

Quadrant IV: Relatively lagging

This quadrant is occupied by the entertainment tax and the parking tax. Although experiencing significant growth, it is influenced by several other factors. Especially for entertainment, the increase in quantity is relatively stagnant due to sociocultural factors; while for parking tax, it is due to the lack of professional management of parking lots.

\section{Conclusion}

Referring to the results of the contribution analysis, it can be said that five (5) types of sub-taxes have an average contribution rate of $36.20 \%$ to Regional 
Original Income, and this value is in the sufficient category. It can be stated that it is in middle category and has good potential to be the next level of category. This level of contribution shows that the Regional Government of Majalengka Regency is expected to be able to further optimize tax collection so that the predetermined target can be achieved. In growth, entertainment tax has grown rapidly but the amount was not increased. It is predicted caused by social capital in Majalengka regency.

Based on overlay map, it is clear that restaurant tax has become the priority for tax collection and the hotel tax has been put as the potential tax in the future. In other side, entertainment tax has been depressed due to social constraints, and parking tax due to the lack of professional management.

In general, the existence of Kertajati Airport has made a change in social economic life of Majalengka society. There is an expanding of business scale not only around the airport, but also in other area including highland. The policy of agrotourism becomes a proper choice to develop Majalengka region since most of it is the agricultural sector.

\section{References}

Arief, F., \& Gill. (2011). Economic and Community Capacity Building for Tourism Development. J Hum Ecol, 27(1), 21-25.

Arikunto, S, 2006. (2012). sampel penelitian. Sampel Penelitian.

Arikunto. (2007). Prosedur Penelitian; Suatu Pendekatan Praktik. Rineka Cipta.

Carpio, C. E., Wohlgenant, M. K., \& Boonsaeng, T. (2008). The demand for agritourism in the United States. Journal of Agricultural and Resource Economics. https://doi.org/10.2307/41220626

Giaccio, V., Giannelli, A., \& Mastronardi, L. (2018). Explaining determinants of Agri-tourism income: evidence from Italy. Tourism Review. https://doi. org/10.1108/TR-05-2017-0089

Giaccio, V., Mastronardi, L., Marino, D., Giannelli, A., \& Scardera, A. (2018). Do rural policies impact on tourism development in Italy? A case study of agritourism. Sustainability (Switzerland). https://doi.org/10.3390/su10082938

Jęczmyk, A., Uglis, J., Graja-Zwolińska, S., Maćkowiak, M., Spychała, A., \& Sikora, J. (2015). Research note: Economic benefits of agritourism development in Poland -An empirical study. Tourism Economics. https://doi.org/10.5367/ te. 2014.0391

Jolink, A., \& Niesten, E. (2015). Sustainable Development and Business Models of Entrepreneurs in the Organic Food Industry. Business Strategy and the Environment. https://doi.org/10.1002/ bse. 1826

Joshi, P. V., \& Bhujbal, M. B. (2012). AgroTourism A Specialized Rural Tourism: Innovative Product of Rural Market. International Journal of Business and Management.

Kristiana, \& Theodora, S. (2016). Strategi Upaya Pengembangan Pariwisata Berkelanjutan Agrowisata Berbasis Masyarakat Kampung Domba Terpadu Juhut, Provinsi Banten. Jurnal Ilmiah Widya.

Lupi, C., Giaccio, V., Mastronardi, L., Giannelli, A., \& Scardera, A. (2017). Exploring the features of agritourism and its contribution to rural development in Italy. Land Use Policy. https://doi. org/10.1016/j.landusepol.2017.03.002

Marin, D. (2015). Study on the Economic Impact of Tourism and of Agrotourism on Local Communities. Research Journal of Agricultural Science.

Mazilu, M. (2010). The rural tourism and the rural development. Journal of Settlements and Spatial Planning.

Muhammad, M., Hamzah, A., Yassin, S. M., Samah, B. A., Tiraieyari, N., D'Silva, J. L., \& Shaffril, H. A. M. (2012). The socio-economic impact of agrotourism activity on fishing communities in malaysia. International Business Management. https://doi.org/10.3923/ ibm.2012.660.664

Muzha, V. (2013). Pengembangan Agrowisata Dengan Pendekatan Community Based Tourism (Studi Pada Dinas Pariwisata Kota Batu Dan Kusuma Agrowisata Batu). Jurnal Administrasi Publik Mahasiswa Universitas Brawijaya.

Octovido, I. (2014). Analisis Efektivitas dan Kontribusi Pajak Daerah sebagai Sumber Pendapatan Asli Daerah Kota Batu. Jurnal Administrasi Bisnis.

Okech, R., Haghiri, M., \& George, B. (2012). Rural Tourism as a Sustainable Development Alternative: An Analysis with Special Reference to Luanda, Kenya. CULTUR: Revista de Cultura e Turismo.

Polena, E., Qirici, E., \& Zoto, S. (2013). Agrotourism - A Sustainable Development for Rural Area of Korca. European 
Academic Research.

Ratnasari, E. D. (1970). ANALISIS SEKTORSEKTOR PEMBENTUK PDRB DAN PENENTUAN SEKTOR UNGGULAN DI WILAYAH KABUPATEN KEBUMEN. Fokus Bisnis : Media Pengkajian Manajemen Dan Akuntansi. https://doi.org/10.32639/ fokusbisnis.v13i1.8

Siren, J. M. (2016). ANALISIS PERTUMBUHAN KAWASAN PENGEMBANGAN EKONOMI TERPADU (KAPET) BIAK DI PROVINSI PAPUA. TATALOKA. https://doi. org/10.14710/tataloka.18.1.47-59

Subhilhar. (2018). The role of small agribusiness in regional development: The case of Sumatera Utara province. IOP Conference Series: Earth and Environmental Science. https://doi. org/10.1088/1755-1315/126/1/012070
Sugiono. (2008). Metode penelitian kuantitatif, kualitatif, dan R\&D. Alfabeta. Sugiyono. (2007). Metode Penelitian Pendidikan Pendekatan Kuantitatif, Kualitatif, dan R\&D. Alfabeta.

Sugiyono. (2011). Metode Penelitian Kuantitatif Kualitatif dan R\&D. Alfabeta.

Tiraieyari, N., \& Hamzah, A. (2011). Agritourism: Potential opportunities for farmers and local communities in Malaysia. In African Journal of Agricultural Research. https://doi.org/10.5897/ AJARx11.035

Tirtawinata, Reza, Fachruddin, \& Lisdiana. (1996). Daya Tarik dan Pengelolaan Agrowisata. Penebar Swadaya.

Yeretzian, C. (2017). Coffee. In Springer Handbooks. https://doi. org/10.1007/978-3-319-26932-0_6 